\section{TINDAK PIDANA DALAM MENGOPERASIKAN PESAWAT UDARA MENURUT UNDANG- UNDANG NOMOR 1 TAHUN 2009 TENTANG PENERBANGAN ${ }^{1}$ \\ Oleh : Marzelino A. Monoarfa ${ }^{2}$ \\ Ralfie Pinasang ${ }^{3}$ \\ Max K. Sondakh ${ }^{4}$}

\begin{abstract}
Abstrak
Penelitian ini dilakukan dengan tujuan untuk
\end{abstract} mengetahui bagaimana pengaturan hukum pengoperasian pesawat udara dan bagaimana tindak pidana dalam mengoperasikan pesawat udara menurut Undang-Undang Nomor 1 Tahun 2009 tentang penerbangan. Dengan menggunakan metode penelitian yuridis normatif, disimpulkan: 1. Pengaturan hukum pengoperasian pesawat udara diantaranya dalam mengoperasikan pesawat udara untuk kegiatan angkutan udara wajib memiliki sertifikat. Sertifikat terdiri atas: sertifikat operator pesawat udara (air operator certificate), yang diberikan kepada badan hukum Indonesia yang mengoperasikan pesawat udara sipil untuk angkutan udara niaga; atau sertifikat pengoperasian pesawat udara (operating certificate), yang diberikan kepada orang atau badan hukum Indonesia yang mengoperasikan pesawat udara sipil untuk angkutan udara bukan niaga. Sertifikat diberikan setelah lulus pemeriksaan dan pengujian serta pemohon mendemonstrasikan kemampuan pengoperasian pesawat udara. 2 . Tindak pidana dalam mengoperasikan pesawat udara menurut Undang-Undang Nomor 1 Tahun 2009 Tentang Penerbangan, beberapa diantaranya seperti perbuatan mengoperasikan pesawat udara Indonesia atau pesawat udara asing yang memasuki kawasan udara terlarang atau memasuki kawasan udara terbatas. Mengoperasikan pesawat udara yang tidak mempunyai tanda pendaftaran dan tidak memenuhi standar kelaikudaraan dan tidak memiliki sertifikat operator pesawat udara serta tidak memiliki sertifikat pengoperasian pesawat udara dan tindak pidana lainnya khusus mengenai operasi pesawat udara

\footnotetext{
${ }^{1}$ Artikel Skripsi

2 Mahasiswa pada Fakultas Hukum Unsrat, NIM. 16071101437

${ }^{3}$ Fakultas Hukum Unsrat, Doktor Ilmu Hukum

${ }^{4}$ Fakultas Hukum Unsrat, Magister Ilmu Hukum
}

sebagaimana diatur dalam Undang-Undang Nomor 1 Tahun 2009 Tentang Penerbangan.

Kata kunci: Tindak Pidana, Mengoperasikan Pesawat Udara, Penerbangan

\section{PENDAHULUAN}

\section{A. Latar Belakang}

Menjamurnya maskapai penerbangan dalam kurun waktu 10 tahun terakhir di satu sisi memberikan implikasi positif bagi masyarakat pengguna jasa penerbangan, yaitu banyak pilihan atas operator penerbangan dengan berbagai ragam pelayanannya. Di samping itu, banyaknya maskapai penerbangan telah menciptakan iklim yang kompetitif antara satu mas kapai penerbangan dengan maskapai penerbangan lainya yang pada ujungnya melahirkan tiket murah yang diburu masyarakat secara antusias. Namun, kompetisi ini pada sisi lain juga menimbulkan kekhawatiran bahwa harga tiket murah akan berdampak pada kualitas layanan, khususnya layanan atas perawatan pesawat. Kekhawatiran tersebut muncul akibatnya sering terjadinya kecelakaan pesawat terbang. ${ }^{5}$

Dalam hal ini pengangkut atau maskapai penerbangan berkewajiban untuk mengangkut penumpang dengan aman dan selamat sampai di tempat tujuan secara tepat waktu, dan sebagai konpensasi dari pelaksanaan kewajibannya tersebut maka perusahaan penerbangan mendapatkan bayaran sebagai ongkos penyelenggaran pengangkutan dari penumpang. ${ }^{6}$

Pesawat terbang merupakan moda transportasi yang paling efektif dan efisien dalam melakukan perpindahan dari satu tempat ke tempat yang lain. Namun dilain sisi, pesawat terbang juga merupakan alat transportasi yang memiliki tingkat risiko kecelakaan yang tinggi. Dari tahun 2010-2016, di Indonesia telah terjadi 26 insiden serius dan 15 kecelakaan (KNKT, 2016). Angka kejadian tersebut jika dipersentasekan mencapai $20 \%$ dari seluruh kejadian kecelakaan dan insiden selama 7 tahun terakhir (KNKT, 2016). ${ }^{7}$

\footnotetext{
${ }^{5}$ Ashar Sinilele. Perlindungan Hukum Terhadap Penumpang Pada Transportasi Udara Niaga Pada Bandara Sultan Hasanuddin Makassar. Vol. 5 / No. 2 / Desember 2016. hlm. 192.

${ }^{6}$ Ibid. hlm. 192.

${ }^{7}$ Mona Lestari, Annisa Rahmawaty, Fenny Etrawati, Nova Apriza Cahyani, Shinta Dwi Kasih, Masayu Gemala Rabiah
} 
Awak pesawat dalam hal ini pilot dan copilot tentunya telah memiliki sertifikat atau lisensi untuk mengendarai pesawat. Selain itu, menurut Rahimudin (2015) seluruh awak pesawat terutama pilot dan co-pilot secara rutin melakukan berbagai macam jenis pelatihan, seperti latihan kesiapsiagaan dalam menghadapi situasi darurat dan Crew Management Resources (CRM), dilakukan uji keterampilan secara berkala untuk memastikan mereka tetap layak menerbangkan pesawat. Prosedur-prosedur diatas dimaksudkan untuk tetap memastikan keterampilan, kemampuan fisik dan psikologi mereka tetap dipertahankan dan mampu menerbangkan pesawat dengan aman. ${ }^{8}$

Menurut Kansil dalam pergaulan masyarakat terdapat aneka macam hubungan di antara anggota masyarakat, yakni hubungan yang ditimbulkan oleh kepentingan-kepentingan anggota masyarakat itu, karena beraneka ragamnya hubungan itu, para anggota masyarakat memerlukan aturan-aturan yang dapat menjamin keseimbangan agar dalam hubungan-hubungan itu tidak terjadi kekacauan di dalam masyarakat. ${ }^{9}$

Peraturan-peraturan hukum yang bersifat mengatur dan memaksa anggota masyarakat untuk patuh dalam menaatinya akan menciptakan keseimbangan dalam setiap hubungan di dalam masyarakat. Setiap pelanggaran atas peraturan yang ada akan dikenakan sanksi atau hukuman sebagai reaksi terhadap perbuatan yang melanggar peraturan. ${ }^{10}$

Untuk menjaga agar peraturan-peraturan itu dapat berlangsung terus-menerus dan diterima oleh seluruh anggota masyarakat, aturan hukum yang ada harus sesuai dan tidak boleh bertentangan dengan rasa keadilan masyarakat. Dengan demikian, hukum bertujuan untuk menjamin adanya kepastian hukum dalam masyarakat dan harus

dan Reza Ardiansyah. Persepsi Risiko Penumpang Pesawat Terbang. Jurnal Kesehatan. ISSN 1979-7621 (Print). ISSN 2620-7761 (Online). Vol. 11. No. 2. Desember 2018. hlm. 56.

${ }^{8}$ Ibid.

${ }^{9}$ Arus Akbar Silondae dan Wirawan B. Ilyas. Pokok-Pokok Hukum Bisnis. Salemba Empat. Jakarta. 2011. hlm. 3.

${ }^{10}$ Ibid. bersendikan pada keadilan yaitu rasa keadilan masyarakat. ${ }^{11}$

\section{B. Rumusan Masalah}

1. Bagaimanakah pengaturan hukum pengoperasian pesawat udara ?

2. Bagaimanakah tindak pidana dalam mengoperasikan pesawat udara menurut Undang-Undang Nomor 1 Tahun 2009 tentang penerbangan?

\section{Metode Penelitian}

Metode penelitian hukum untuk penyusunan penulisan yang digunakan ialah metode penelitian hukum normatif. Bahanbahan hukum yang digunakan diperoleh melalui studi kepustakaan dan terdiri dari bahan hukum primer ialah: peraturan perundang-undangan di bidang penerbangan dan bahan hukum sekunder terdiri dari literatur-literatur, jurnal hukum dan artikel hukum serta bahan hukum tersier terdiri dari kamus umum dan kamus hukum yang dapat digunakan untuk memberikan penjelasan berupa pengertian dari beberapa istilah-istilah hukum yang digunakan dalam penulisan ini. Bahan-bahan hukum primer dan sekunder dianalisis secara kualitatif normatif.

\section{PEMBAHASAN}

\section{A. Pengaturan Hukum Pengoperasian Pesawat Udara}

Penerbangan yang mempunyai karakteristik dan keunggulan tersendiri, perlu dikembangkan agar mampu meningkatkan pelayanan yang lebih luas, baik domestik maupun internasional. Pengembangan penerbangan ditata dalam satu kesatuan sistem dengan mengintegrasikan dan mendinamisasikan prasarana dan sarana penerbangan, metoda, prosedur, dan peraturan sehingga berdaya guna serta berhasil guna. ${ }^{12}$

Dalam penyelenggaraan penerbangan, Undang-Undang ini bertujuan mewujudkan penerbangan yang tertib, teratur, selamat, aman, nyaman, dengan harga yang wajar, dan menghindari praktek persaingan usaha yang tidak sehat, memperlancar arus perpindahan orang dan/atau barang melalui udara dengan mengutamakan dan melindungi angkutan

\footnotetext{
${ }^{11} \mathrm{lbid}$.

12 Penjelasan Atas Undang-Undang Nomor 1 Tahun 2009 tentang Penerbangan.
} 
udara dalam rangka memperlancar kegiatan perekonomian nasional, membina jiwa kedirgantaraan, menjunjung kedaulatan negara, menciptakan daya saing dengan mengembangkan teknologi dan industri angkutan udara nasional, menunjang, menggerakkan, dan mendorong pencapaian tujuan pembangunan nasional, memperkukuh kesatuan dan persatuan bangsa dalam rangka perwujudan Wawasan Nusantara, meningkatkan ketahanan nasional, dan mempererat hubungan antarbangsa, serta berasaskan manfaat, usaha bersama dan kekeluargaan, adil dan merata, keseimbangan, keserasian dan keselarasan, kepentingan umum, keterpaduan, tegaknya hukum, kemandirian, anti monopoli dan keterbukaan, berwawasan lingkungan hidup, kedaulatan negara, kebangsaan, serta kenusantaraan. ${ }^{13}$

Undang-Undang Nomor 1 Tahun 2009 Tentang Penerbangan. Pasal 1 angka 51. Sertifikat Kompetensi adalah tanda bukti seseorang telah memenuhi persyaratan pengetahuan, keahlian, dan kualifikasi di bidangnya.

Undang-Undang Nomor 1 Tahun 2009 Tentang Penerbangan. Operasi Pesawat Udara. Pasal 1 angka 51. Sertifikat Kompetensi adalah tanda bukti seseorang telah memenuhi persyaratan pengetahuan, keahlian, dan kualifikasi di bidangnya.

Undang-Undang Nomor 1 Tahun 2009 Tentang Penerbangan. Operasi Pesawat Udara. Pasal 41 ayat:

(1) Setiap orang yang mengoperasikan pesawat udara untuk kegiatan angkutan udara wajib memiliki sertifikat.

(2) Sertifikat sebagaimana dimaksud pada ayat (1) terdiri atas:

a. sertifikat operator pesawat udara (air operator certificate), yang diberikan kepada badan hukum Indonesia yang mengoperasikan pesawat udara sipil untuk angkutan udara niaga; atau

b. sertifikat pengoperasian pesawat udara (operating certificate), yang diberikan kepada orang atau badan hukum Indonesia yang mengoperasikan pesawat udara sipil untuk angkutan udara bukan niaga.

\footnotetext{
${ }^{13}$ Penjelasan Atas Undang-Undang Nomor 1 Tahun 2009 tentang Penerbangan.
}

(3) Sertifikat sebagaimana dimaksud pada ayat (2) diberikan setelah lulus pemeriksaan dan pengujian serta pemohon mendemonstrasikan kemampuan pengoperasian pesawat udara.

Pasal 42. Untuk mendapatkan sertifikat operator pesawat udara sebagaimana dimaksud dalam Pasal 41 ayat (2) huruf a operator harus:

a. memiliki izin usaha angkutan udara niaga;

b. memiliki dan menguasai pesawat udara sesuai dengan izin usaha yang dimiliki;

c. memiliki dan/atau menguasai personel pesawat udara yang kompeten dalam jumlah rasio yang memadai untuk mengoperasikan dan melakukan perawatan pesawat udara;

d. memiliki struktur organisasi paling sedikit di bidang operasi, perawatan, keselamatan, dan jaminan kendali mutu;

e. memiliki personel manajemen yang kompeten dengan jumlah memadai;

f. memiliki dan/atau menguasai fasilitas pengoperasian pesawat udara;

g. memiliki dan/atau menguasai persediaan suku cadang yang memadai;

h. memiliki pedoman organisasi pengoperasian (company operation manual)dan pedoman organisasi perawatan (company maintenance manual);

i. memiliki standar keandalan pengoperasian pesawat udara (aircraft operating procedures);

j. memiliki standar perawatan pesawat udara;

k. memiliki fasilitas dan pedoman pendidikan dan/atau pelatihan personel pesawat udara (company training manuals);

I. memiliki sistem jaminan kendali mutu (company quality assurance manuals) untuk mempertahankan kinerja operasi dan teknik secara terus menerus; dan

m. memiliki pedoman sistem manajemen keselamatan (safety management system manual).

Penjelasan 42 huruf (e) Yang dimaksud dengan "personel manajemen yang kompeten" adalah personel yang telah memiliki sertifikat kecakapan.

B. Tindak Pidana Dalam Mengoperasikan Pesawat Udara Menurut Undang-Undang Nomor 1 Tahun 2009 Tentang Penerbangan 
Undang-Undang Nomor 1 Tahun 2009 Tentang Penerbangan. Pasal 401.Setiap orang yang mengoperasikan pesawat udara Indonesia atau pesawat udara asing yang memasuki kawasan udara terlarang sebagaimana dimaksud dalam Pasal 7 ayat (2) dipidana dengan pidana penjara paling lama 8 (delapan) tahun dan denda paling banyak Rp500.000.000,00 (lima ratus juta rupiah).

Pasal 402. Setiap orang yang mengoperasikan pesawat udara Indonesia atau pesawat udara asing yang memasuki kawasan udara terbatas sebagaimana dimaksud dalam Pasal 7 ayat (4) dipidana dengan pidana penjara paling lama 3 (tiga) tahun atau denda paling banyak Rp500.000.000,00 (lima ratus juta rupiah).

Undang-Undang Nomor 1 Tahun 2009 Tentang Penerbangan. Pasal 404. Setiap orang yang mengoperasikan pesawat udara yang tidak mempunyai tanda pendaftaran sebagaimana dimaksud dalam Pasal 24 dipidana dengan pidana penjara paling lama 5 (lima) tahun atau denda paling banyak Rp1.000.000.000,00 (satu miliar rupiah).

Konvensi Penerbangan Sipil Internasional (Chicago, 1944) (selanjutnya disebut sebagai Konvensi Chicago) hanya menyatakan bahwa pesawat udara akanmemiliki nasionalitas negara dimana pesawat tersebut didaftarkan.(Pasal 17 Konvensi Chicago). ${ }^{14}$

Pasal 20 menyatakan bahwa setiap pesawat udara yang beroperasi dalam penerbangan internasional harus memiliki nasionalitas dan tanda pandaftaran. Hal tersebut lebih lengkap dijelaskan dalam annex 7 pada Konvensi Chicago yang mengharuskan tanda nasionalitas dan pendaftaran itu untuk dicatkan pada badan pesawat atau ditempelkan dengan cara apapun asalkan bersifat permanen. Standar ini juga mengharuskan agar tanda tersebut dijaga kebersihannya sehingga tetap terlihat oleh operator sepanjang waktu (Lihat annex 7 pada Convention on International Civil Aviation).

Pasal 21 mengharuskan agar setiap negara yang memberikan nasionalitas kepada suatu pesawat saat diminta bisa memberikan keterangan pada ICAO atau negara lain yang meminta informasi mengenai pendaftaran dan kepemilikan pesawat apapun yang didaftarkan

\footnotetext{
${ }^{14}$ Agus Pramono. Aspek Hukum Pendaftaran Pesawat Udara. Pandecta. Volume 8. Nomor 2. Juli 2013.hlm. 240.
}

dinegara tersebut (Konvensi Chicago, 2 pasal 21). ${ }^{15}$

Undang-Undang Nomor 1 Tahun 2009 Tentang Penerbangan. Pasal 406 ayat:

(1) Setiap orang yang mengoperasikan pesawat udara yang tidak memenuhi standar kelaikudaraan sebagaimana dimaksud dalam Pasal 34 dipidana dengan pidana penjara paling lama 3 (tiga) tahun atau denda paling banyak Rp1.500.000.000,00 (satu miliar lima ratus juta rupiah).

(2) Jika perbuatan sebagaimana dimaksud pada ayat (1) menimbulkan kerugian harta benda dipidana dengan pidana penjara paling lama 4 (empat) tahun atau denda paling banyak Rp2.000.000.000,00 (dua miliar rupiah).

(3) Jika perbuatan sebagaimana dimaksud pada ayat (1) mengakibatkan kematian seseorang dan kerugian harta benda, dipidana dengan pidana penjara paling lama 10 (sepuluh) tahun dan denda paling banyak Rp2.500.000.000,00 (dua miliar lima ratus juta rupiah).

Pasal 407. Setiap orang yang mengoperasikan pesawat udara yang tidak memiliki sertifikat operator pesawat udara sebagaimana dimaksud dalam Pasal 41 ayat (2) huruf a dipidana dengan pidana penjara paling lama 2 (dua) tahun atau denda paling banyak Rp2.500.000.000,00 (dua miliar lima ratus juta rupiah).

Pasal 408. Setiap orang yang mengoperasikan pesawat udara yang tidak memiliki sertifikat pengoperasian pesawat udara sebagaimana dimaksud dalam Pasal 41 ayat (2) huruf $b$ dipidana dengan pidana penjara paling lama 1 (satu) tahun atau denda paling banyak Rp500.000.000,00 (lima ratus juta rupiah).

Pasal 410.Setiap orang yang mengoperasikan pesawat udara sipil Indonesia atau asing yang tiba di atau berangkat dari Indonesia dan melakukan pendaratan dan/atau tinggal landas dari bandar udara yang tidak sesuai dengan ketentuan dalam Pasal 52 dipidana dengan pidana penjara 1 (satu) tahun atau denda Rp500.000.000,00 (lima ratus juta rupiah).

\footnotetext{
${ }^{15}$ Ibid.hlm. 244.
} 
Pasal 411. Setiap orang dengan sengaja menerbangkan atau mengoperasikan pesawat udara yang membahayakan keselamatan pesawat udara, penumpang dan barang, dan/atau penduduk atau merugikan harta benda milik orang lain sebagaimana dimaksud dalam Pasal 53 dipidana dengan pidana penjara paling lama 2 (dua) tahun dan denda paling banyak Rp500.000.000,00 (lima ratus juta rupiah).

Undang-Undang Nomor 1 Tahun 2009 Tentang Penerbangan. 50. Lisensi adalah surat izin yang diberikan kepada seseorang yang telah memenuhi persyaratan tertentu untuk melakukan pekerjaan di bidangnya dalam jangka waktu tertentu.

Pasal 413 ayat:

(1) Setiap personel pesawat udara yang melakukan tugasnya tanpa memiliki sertifikat kompetensi atau lisensi sebagaimana dimaksud dalam Pasal 58 ayat (1) dipidana dengan pidana penjara paling lama 1 (satu) tahun atau denda paling banyak Rp200.000.000,00 (dua ratus jutarupiah).

(2) Dalam hal perbuatan sebagaimana dimaksud pada ayat (1) mengakibatkan matinya orang, dipidana dengan pidana penjara paling lama 15 (lima belas) tahun dan denda paling banyak Rp1.000.000.000,00 (satu miliar rupiah).

Pasal 414. Setiap orang yang mengoperasikan pesawat udara asing di wilayah Negara Kesatuan Republik Indonesia tanpa izin Menteri sebagaimana dimaksud dalam Pasal 63 ayat (2) dipidana dengan pidana penjara paling lama 5 (lima) tahun atau denda paling banyak Rp2.000.000.000,00 (dua miliar rupiah).

Pasal 415. Setiap orang yang mengoperasikan pesawat udara sipil asing yang dioperasikan di wilayah Negara Kesatuan Republik Indonesia yang tidak memenuhi persyaratan kelaikudaraan sebagaimana dimaksud dalam Pasal 63 ayat (4) dipidana dengan pidana penjara paling lama 5 (lima) tahun atau denda paling banyak Rp2.000.000.000,00 (dua miliar rupiah).

Pada dewasa ini, hampir dapat dipastikan bahwa semua jenis atau bentuk kejahatan tidak lagi dapat hanya dipandang sebagai yurisdiksi kriminal satu negara, akan tetapi sering diklaim termasuk yurisdiksi kriminal lebih dari satu atau dua negara sehingga dalam perkembangannya, kemudian telah menimbulkan masalah konflik yurisdiksi yang sangat mengganggu hubungan internasional antarnegara yang berkepentingan di dalam kasus tindak pidana tertentu yang bersifat lintas batas teritorial. Masyarakat internasional yang tergabung dalam wadah Perserikatan Bangsa-Bangsa mengakui bahwa perkembangan tindak pidana lintas batas antarnegara dalam upaya pencegahan dan pemberantasannya terutama jika dalam tindak pidana tersebut terlibat warga negara asing. ${ }^{16}$

Dalam hal ini terjadinya kejahatan itu mungkin di wilayah negara lain atau di suatu tempat di luar wilayah negara, seperti telah dikemukakan di atas dan atas kejahatan tersebut ada kepentingan nasional dari suatu negara atau lebih yang terkait dengan kejahatan itu, misalnya kejahatan itu menimbulkan korban di dalam wilayahnya atau yang menjadi korban adalah warganegaranya sendiri ataupun korban-korban lain yang pada dasarnya merugikan negara yang bersangkutan, negara itu tentu saja berkepentingan untuk mengaturnya di dalam hukum atau peraturan perundang-undangan pidana nasionalnya, menerapkannya terhadap si pelakunya serta mengadili dan jika terbukti bersalah selanjutnya adalah menghukum dan mengeksekusinya di dalam wilayahnya sendiri. ${ }^{17}$ Dalam rangka menunjang terpeliharanya stabilitas dan kepentingan nasional, kedaulatan negara, keamanan dan ketertiban umum dan kewaspadaan terhadap segala dampak negatif yang timbul akibat perlintasan orang antarnegara, keberadaan dan kegiatan orang asing di wilayah Negara Republik Indonesia, perlu melakukan pengawasan bagi orang asing dan tindakan keimigrasian secara cepat, teliti dan terkoordinasi, tanpa mengabaikan keterbukaan dalam memberikan pengawasan bagi orang asing. ${ }^{18}$

\footnotetext{
${ }^{16}$ Romli Atmasasmita, Pengantar Hukum Pidana Internasional, Refika Aditama, Cetakan, Pertama. Bandung. 2000, hlm. 5.

${ }^{17}$ I. Wayan Parthiana, Hukum Pidana Internasional, Cet. I. Yrama Widya, Bandung, 2006, hlm. 31-30.

${ }^{18}$ Siswanto Sunarso, Ekstradisi \& Bantuan Timbal Balik Dalam Masalah Pidana Instrumen Penegakan Hukum Pidana Internasional, Rineka Cipta, Jakarta. 2009.hlm. 206-207.
} 
Pelaksanaan pengawasan orang asing merupakan wewenang dan tanggung jawab Menteri Hukum dan HAM, untuk melakukan keberadaan serta kegiatannya di wilayah Negara Republik Indonesia, serta mengkoordinasikan pelaksanaan tugas badan atau instansi pemerintah yang terkait dalam pengawasan orang asing. Dalam rangka pengawasan orang asing, maka diperlukan menghimpun data dan informasi setiap orang yang masuk atau ke luar wilayah negara Republik Indonesia, berada di wilayah negara Republik Indonesia; dan melakukan kegiatan di wilayah negara Republik Indonesia. ${ }^{19}$

Tatacara penindakan keimigrasian ditetapkan dengan keputusan tertulis oleh pejabat Imigrasi yang berwenang dan disampaikan selambat-lambatnya tujuh hari terhitung sejak tanggal penetapan kepada orang asing yang dikenakan tindakan. Setiap orang asing yang terkena tindakan dapat mengajukan keberatan kepada Menteri dalam jangka waktu tiga hari sejak tanggal diterimanya keputusan tindakan keimigrasian tersebut. Tindakan keimigrasian dapat pula dilakukan secara tindakan administratif di bidang keimigrasian di luar proses peradilan dan ditetapkan secara tertulis. ${ }^{20}$

Beberapa sarjana hukum mengemukakan tentang tujuan hukum pidana, ialah:

a. Untuk menakut-nakuti orang jangan sampai melakukan kejahatan, baik dengan menakutnakuti orang banyak (generale preventie), maupun secara menakut-nakuti orang tertentu yang sudah menjalankan kejahatan, agar dikemudian hari tidak melakukan kejahatan lagi (special prventie);

b. Untuk mendidik atau memperbaiki orangorang yang suka melakukan kejahatan agar menjadi orang yang baik tabiatnya, sehingga bermanfaat bagi masyarakat;

c. Untuk mencegah dilakukannya tindak pidana demi pengayoman negara, masyarakat dan penduduk, yakni:

1) Untuk membimbing agar terpidana insaf dan menjadi anggota masyarakat yang berbudi baik dan berguna;
2) Untuk menghilangkan noda-noda yang diakibatkan oleh tindak pidana. ${ }^{21}$

Undang-Undang Nomor 1 Tahun 2009

Tentang Penerbangan. Pasal 422 ayat:

(1) Setiap orang dengan sengaja mengoperasikan bandar udara tanpa memenuhi ketentuan keselamatan dan keamanan penerbangan sebagaimana dimaksud dalam Pasal 217 ayat (1) dipidana dengan pidana penjara paling lama 3 (tiga) tahun dan denda paling banyak Rp1.000.000.000,00 (satu miliar rupiah).

(2) Dalam hal perbuatan sebagaimana dimaksud pada ayat (1) menimbulkan kerugian harta benda seseorang, dipidana dengan pidana penjara paling lama 5 (lima) tahun dan denda paling banyak Rp2.000.000.000,00 (dua miliar rupiah).

(3) Dalam hal perbuatan sebagaimana dimaksud pada ayat (1) mengakibatkan matinya orang, dipidana dengan pidana penjara paling lama 15 (lima belas) tahun dan denda paling banyak Rp5.000.000.000,00 (lima miliar rupiah).

Pasal 427. Setiap orang yang mengoperasikan bandar udara khusus dengan melayani penerbangan langsung dari dan/atau ke luar negeri tanpa izin dari Menteri sebagaimana dimaksud dalam Pasal 249, dipidana dengan pidana penjara paling lama 3 (tiga) tahun atau denda paling banyak Rp3.000.000.000,00 (tiga miliar rupiah).

Pasal 428 ayat:

(1) Setiap orang yang mengoperasikan bandar udara khusus yang digunakan untuk kepentingan umum tanpa izin dari Menteri sebagaimana dimaksud dalam Pasal 250 dipidana dengan pidana penjara paling lama 3 (tiga) tahun atau denda paling banyak Rp3.000.000.000,00 (tiga miliar rupiah).

(2) Dalam hal tindak pidana sebagaimana dimaksud pada ayat (1) mengakibatkan matinya orang dipidana dengan pidana penjara paling lama 15 (lima belas) tahun dan denda paling banyak Rp15.000.000.000,00 (lima belas miliar rupiah).

\footnotetext{
${ }^{21}$ Siswantoro Sunarso, Hukum Pidana Lingkungan Hidup Dan Strategi Penyelesaian Sengketa, Cetakan Pertama, Rineka Cipta, Jakarta, 2005, hlm. 73.
}

${ }^{19}$ Ibid, hlm. 207.

${ }^{20} \mathrm{lbid}$. 
Pasal 434. Setiap orang yang mengoperasikan pesawat udara kategori transpor tidak memenuhi persyaratan keamanan penerbangan sebagaimana dimaksud dalam Pasal 342 sehingga mengakibatkan kecelakaan pesawat udara dan kerugian harta benda, dipidana dengan pidana penjara 5 (lima) tahun dan denda paling banyak Rp1.000.000.000,00 (satu miliar rupiah).

Pasal 443. Dalam hal tindak pidana di bidang penerbangan dilakukan oleh suatu korporasi, selain pidana penjara dan denda terhadap pengurusnya, pidana yang dapat dijatuhkan terhadap korporasi berupa pidana denda dengan pemberatan 3 (tiga) kali dari pidana denda yang ditentukan dalam Bab ini.

Korporasi juga termasuk badan hukum (rechtpersoon) yaitu dengan menunjuk pada adanya suatu badan yang diberi status sebagai subjek hukum, disamping subjek hukum yang berwujud manusia alamiah (natuurlijk persoon). Selanjutnya korporasi mulai memasuki lingkup hukum pidana sebagai subjek hukum sejak munculnya fenomenafenomena kejahatan korporasi. ${ }^{22}$

Korporasi ialah kumpulan orang dan/atau kekayaan yang terorganisasi baik merupakan badan hukum maupun bukan badan hukum. ${ }^{23}$ Badan hukum hukum ialah suatu badan yang ada karena hukum dan memang diperlukan keberadaannya sehingga disebut legal entity. ${ }^{24}$

Badan hukum ialah badan atau perkumpulan yang dalam lalu lintas hukum diakui sebagai subjek hukum seperti perseroan, yayasan, lembaga dan sebagainya. ${ }^{25}$

Korporasi sebagai subjek hukum tidak hanya menjalankan kegiatannya sesuai dengan prinsip ekonomi (mencari keuntungan yang sebesarbesarnya), tetapi juga mempunyai kewajiban untuk mematuhi peraturan hukum di bidang ekonomi yang digunakan pemerintah guna mewujudkan kesejahteraan masyarakat dan keadilan sosial. ${ }^{26}$ Hukum pidana adalah hukum yang mengatur tentang pelanggaran dan

\footnotetext{
${ }^{22}$ Muhammad Yamin, Tindak Pidana Khusus, Cet. 1. Pustaka Setia, Bandung, 2012. hlm. 89.

${ }^{23}$ Rocky Marbun, Deni Bram, Yuliasara Isnaeni dan Nusya A., Op.Cit.hlm. 169.

${ }^{24}$ Ibid, hlm. 30.

${ }^{25}$ Sudarsono, Kamus Hukum, Op.Cit.hlm. 41.

${ }^{26}$ Alvi Syahrin, Beberapa Isu Hukum Lingkungan Kepidanaan, Cetakan Revisi, PT. Sofmedia, Jakarta, 2009.hlm.59.
}

kejahatan terhadap kepentingan umum. Pelanggaran dan kejahatan tersebut diancam dengan hukuman yang merupakan penderitaan atau siksaan bagi yang bersangkutan. Kejahatan adalah perbuatan pidana yang berat. Ancaman hukumannya dapat berupa hukuman denda, hukuman penjara, hukuman mati dan kadangkala masih ditambah dengan hukuman penyitaan barang-barang tertentu, pencabutan hak-hak tertentu serta pengumuman keputusan hakim. ${ }^{27}$

\section{PENUTUP}

\section{A. Kesimpulan}

1. Pengaturan hukum pengoperasian pesawat udara diantaranya dalam mengoperasikan pesawat udara untuk kegiatan angkutan udara wajib memiliki sertifikat. Sertifikat terdiri atas: sertifikat operator pesawat udara (air operator certificate), yang diberikan kepada badan hukum Indonesia yang mengoperasikan pesawat udara sipil untuk angkutan udara niaga; atau sertifikat pengoperasian pesawat udara (operating certificate), yang diberikan kepada orang atau badan hukum Indonesia yang mengoperasikan pesawat udara sipil untuk angkutan udara bukan niaga. Sertifikat diberikan setelah lulus pemeriksaan dan pengujian serta pemohon mendemonstrasikan kemampuan pengoperasian pesawat udara.

2. Tindak pidana dalam mengoperasikan pesawat udara menurut Undang-Undang Nomor 1 Tahun 2009 Tentang Penerbangan, beberapa diantaranya seperti perbuatan mengoperasikan pesawat udara Indonesia atau pesawat udara asing yang memasuki kawasan udara terlarang atau memasuki kawasan udara terbatas. Mengoperasikan pesawat udara yang tidak mempunyai tanda pendaftaran dan tidak memenuhi standar kelaikudaraan dan tidak memiliki sertifikat operator pesawat udara serta tidak memiliki sertifikat pengoperasian pesawat udara dan tindak pidana lainnya khusus mengenai operasi pesawat udara

\footnotetext{
${ }^{27}$ Yulies Tiena Masriani, Op.Cit. hlm. 60.
} 
sebagaimana diatur dalam UndangUndang Nomor 1 Tahun 2009 Tentang Penerbangan.

\section{B. Saran}

1. Pengaturan hukum pengoperasian pesawat udara memerlukan pengawasan keselamatan penerbangan yang berkelanjutan untuk melihat pemenuhan peraturan keselamatan penerbangan yang dilaksanakan oleh penyedia jasa penerbangan dan pemangku kepentingan lainnya yang meliputi: audit; inspeksi; pengamatan (surveillance); dan pemantauan (monitoring) yang dilakukan oleh unit kerja atau lembaga penyelenggara pelayanan umum. Terhadap hasil pengawasan Menteri melakukan tindakan korektif dan penegakan hukum. Tindakan hukum dapat berupa: sanksi administratif; dan sanksi pidana.

2. Tindak pidana dalam mengoperasikan pesawat udara menurut Undang-Undang Nomor 1 Tahun 2009 Tentang Penerbangan apabila telah terbukti sah menurut hukum telah dilakukan oleh pelakunya, maka sanksi pidana perlu diterapkan sesuai dengan perbuatan sebagaimana diatur dalam peraturan perundang-undangan guna memberikan efek jera dan bagi pihak lain sebagai peringata untuk tidak melakukan perbuatan yang sama.

\section{DAFTAR PUSTAKA}

Adolf Huala, Aspek-Aspek Negara Dalam Hukum Internasional, Keni Media Bandung. 2011.

Adrianti Agustia Alyssa, Agus Pramono, dan H.M Kabul Supriyadhie.Tinjauan Hukum Mengenai Pendaftaran Pesawat Udara Sipil Di Indonesia Berdasarkan Konvensi Chicago 1944 Dan Undang-Undang Nomor 1 Tahun 2009 Tentang Penerbangan. Diponegoro Law Journal Volume 6, Nomor 2, Tahun 2017.

Atmasasmita Romli, Pengantar Hukum Pidana Internasional, Refika Aditama, Cetakan, Pertama. Bandung. 2000.
Djamali Abdoel. Pengantar Hukum Indonesia. Rajawali Pers. PT. Raja Grafindo Persada. Jakarta. 2009.

Hadari Nawawi,. Pengawasan Melekat di Lingkungan Aparatur Pemerintah. Gelora Aksara Pratama, Jakarta. 1992.

Hadjon M. Philipus. dkk. Pengantar Hukum Administrasi Indonesia, Gadjah Mada Press University Yogyakarta. 2002.

Hamzah Andi, Terminologi Hukum Pidana, (Editor) Tarmizi, Ed. 1. Cet. 1. Sinar Grafika, Jakarta, 2008.

HR. Ridwan. Hukum Administrasi Negara. UII Press. Yogyakarta. 2003.

Husni Lalu, Penyelesaian Perselisihan Hubungan Industrial Melalui Pengadilan \& Di Luar Pengadilan, Raja Grafindo Persada, Jakarta, 2004.

Kansil C.S.T., Christine S.T. Kansil, Engelien R. Palandeng dan Godlieb N. Mamahit, Op.Cit, Kamus Istilah Aneka Hukum, Edisi Pertama, Cetakan Kedua, Jala Permata Aksara, Jakarta, 2010.

Lestari Mona, Annisa Rahmawaty, Fenny Etrawati, Nova Apriza Cahyani, Shinta Dwi Kasih, Masayu Gemala Rabiah dan Reza Ardiansyah. Persepsi Risiko Penumpang Pesawat Terbang. Jurnal Kesehatan. ISSN 1979-7621 (Print). ISSN 2620-7761 (Online). Vol. 11. No. 2. Desember 2018.

Machmud Syahrul. Penegakan Hukum Lingkungan Indonesia. (Penegakan Hukum Administrasi. Hukum Perdata. Dan Hukum Pidana Menurut UndangUndang No. 32 Tahun 2009) Graha Ilmu. Yogyakarta.Graha Ilmu, Bandung. 2012.

Mahrus Ali, Dasar-Dasar Hukum Pidana, Cetakan Pertama, Sinar Grafika, Jakarta, 2011.

Manurung Batara, Kabul Supriyadhie dan Agus Pramono.Tinjauan Hukum Udara Atas Keselamatan Penerbangan (Studi Kasus Runway Incursion Batik Air Dengan Trans Nusa Indonesia).Diponegoro Law Journal.Volume 6, Nomor 1, Tahun 2017.

Marbun Rocky, Deni Bram, Yuliasara Isnaeni dan Nusya A., Kamus Hukum Lengkap (Mencakup Istilah Hukum \& 
Perundang-Undangan Terbaru, Cetakan Pertama, Visimedia, Jakarta. 2012.

Marbun SF. Pokok-Pokok Hukum Administrasi Negara. Liberty. Yogyakarta. 1997.

Marpaung Leden, Asas-Teori-Praktik Hukum Pidana, Sinar Grafika. Cetakan Kedua, Jakarta, 2005.

Masriani Tiena Yulies. Pengantar Hukum Indonesia, Cetakan Kelima, Sinar Grafika, Jakarta. 2009.

Moeljatno, Asas-Asas Hukum Pidana, Edisi Revisi, PT. Rineka Cipta, Jakarta, 2008.

Mulyadi Mahmud dan Feri Antoni Surbakti, Politik Hukum Pidana Terhadap Kejahatan Korporasi, Cetakan Pertama, PT. Sofmedia, Jakarta. 2010.

Parthiana Wayan I., Hukum Pidana Internasional, Cet. I. Yrama Widya, Bandung, 2006.

Pramono Agus. Aspek Hukum Pendaftaran Pesawat Udara. Pandecta. Volume 8. Nomor 2. Juli 2013.

Prins W.F dan R. Kosim Adisapoetra, Pengantar Hukum Ilmu Administrasi Negara. Pradnya Paramita, Jakarta. 1983.

Putra Bagus Wyasa Ida, Hukum Bisnis Pariwisata, Cetakan Pertama. PT. Refika Aditama, Bandung, 2003.

Ridwan Juniarso H. dan Achmad Sodik Sudrajat, Hukum Adminsitrasi Negara dan Kebijakan Pelayanan Publik, Cetakan I. Nuansa. Bandung. 2010.

Sadjijono. Polri Dalam Perkembangan Hukum Di Indonesia, (Editor) M. Khoidin, LaksBang PRESSindo, Yogyakarta. 2008.

Saputra Dwi Abadi. Studi Analisis Penyebab Runway Excursion di Indonesia Berdasarkan Data Komite Nasional Keselamatan Transportasi (KNKT) Tahun 2007-2016. Runway Excursion Analysis Study in Indonesia Base on National Transportation Safety Committee (NTSC) Database 20072016. Warta Ardhia, Volume 43 No. 2 Desember 2017.

Saputra Dwi Abady, Sigit Priyanto, Imam Muthohar dan Magda Bhinnety. Studi Tingkat Kecelakaan Pesawat Terbang Di Indonesia Dari Tahun 1988-2012 Study of Aircraft Accident Rate In
Indonesia From 1988-2012. Warta Penelitian Perhubungan, Volume 27, Nomor 4, Juli-Agustus 2015.

Sarwoto. Dasar-dasar Organisasi dan Manajemen, Ghalia Indonesia. Jakarta. 1994.

Silondae Akbar Arus dan Wirawan B. Ilyas. Pokok-Pokok Hukum Bisnis. Salemba Empat. Jakarta. 2011.

Sinilele Ashar. Perlindungan Hukum Terhadap Penumpang Pada Transportasi Udara Niaga Pada Bandara Sultan Hasanuddin Makassar. Vol. 5 / No. 2 / Desember 2016.

Soekanto Soerjono. Faktor-Faktor Yang Mempengaruhi Penegakan Hukum, PT. RajaGrafindo Persada. Edisi 1. Cet.4. Jakarta. 2002.

Spelt N.M. dan J.B.J.M. Ten Berge, Pengantar Hukum Perizinan, (Penyunting) Philipus. M. Hadjon, Yuridika. Surabaya. 1993.

Sudarsono, Kamus Hukum, Cetakan Keenam, PT. Rineka Cipta, Jakarta, 2009.

Sudarsono. Pengantar IImu Hukum. PT. Rineka Cipta. Jakarta. 2007.

Sunarso Siswanto, Ekstradisi \& Bantuan Timbal Balik Dalam Masalah Pidana Instrumen Penegakan Hukum Pidana Internasional, Rineka Cipta, Jakarta. 2009.

Sunarso Siswantoro, Hukum Pidana Lingkungan Hidup Dan Strategi Penyelesaian Sengketa, Cetakan Pertama, Rineka Cipta, Jakarta, 2005.

Sutedi Adrian. Hukum Perizinan Dalam Sektor Pelayanan Publik, Sinar Grafika. Jakarta. 2011.

Sutedi Adrian. Hukum Perizinan dalam Sektor Pelayanan Publik. Sinar Grafika. Jakarta. 2009.

Syahrin Alvi, Beberapa Isu Hukum Lingkungan Kepidanaan, Cetakan Revisi, PT. Sofmedia, Jakarta, 2009.

Syamsuddin Aziz. Tindak Pidana Khusus. Sinar Grafika. Jakarta. 2011.

Ukun Wahyudin, Deportasi Sebagai Instrumen Penegakan Hukum dan Kedaulatan Negara di Bidang Keimigrasian. PT. Adi Kencana Aji. Jakarta. 2004.

Winaya Bagus Gde Ida dan Lita Tyesta, A.L.W. Pengaturan Kawasan Keselamatan 
Lex Et Societatis Vol. VIII/No. 4/Okt-Des/2020

Operasi Penerbangan : Studi Tentang Pelaksanaan Kewenangan Pemerintah Daerahdalam Mengendalikan Pembangunan Dan Benda Tumbuh Di Kawasan Keselamatan Operasi Penerbangan Bandar Udara Ahmad Yani Semarang. Jurnal Law Reform Program Studi Magister IImu HukumVolume 12, Nomor 1, Tahun 2016.

Yamin Muhammad, Tindak Pidana Khusus, Cet. 1. Pustaka Setia, Bandung, 2012.

\section{Internet}

https://www.cnnindonesia.com/Maskapai

Diwajibkan Kantongi Sertifikat Operator Pesawat. Diakses 4/12/2020 8:19 Wita. 